\title{
Liberty, Equality, and the Boundaries of Ownership: Thomas Paine's Theory of Property Rights
}

\author{
Robert Lamb
}

\begin{abstract}
Thomas Paine is customarily regarded as a pamphleteer, rhetorician, and polemicist rather than a significant political theorist. This article takes the philosophical content of Paine's thought seriously and argues that his account of property rights constitutes a distinct contribution to theoretical debates on the subject. Drawing on Paine's Agrarian Justice and other writings, this article shows that his theory of property defends a libertarian concern with private ownership that contains within its logic an egalitarian commitment to the redistribution of resources. Paine's justification of property is distinct from that of various other important figures in the history of ideas (including Grotius, Pufendorf, and Locke) and represents his simultaneous commitment to foundational liberal values of individual freedom and moral equality.
\end{abstract}

\section{Introduction}

Thomas Paine is a transatlantic political icon, a plain-speaking revolutionary campaigner whose writings - more than those of any other figure-captured the zeitgeist of the two most significant political events of the eighteenth century: the American and French revolutions. As far as public consciousness is concerned, his enduring political legacy is curiously schizophrenic in that he is lauded at once by the libertarian right in the United States and the socialist and social democratic left in Britain. Despite having been the subject of much valuable scholarly attention throughout the twentieth century, there has been little interest expressed in Paine that has not been of a purely historical or biographical nature. ${ }^{1}$ This is in one sense unsurprising, given his role as

An earlier version of this paper was presented to the Political Theory workshop at the University of York in December 2008. I am grateful to the audience there, especially Matt Matravers and Tim Stanton, to the editor of The Review of Politics and the journal's referees, and to Dario Castiglione, Iain Hampsher-Monk, and Mark Philp for very useful comments.

${ }^{1}$ John Keane's Tom Paine: A Political Life (London: Bloomsbury, 1995) is the most impressive and comprehensive biographical treatment of Paine. Previous treatments 
a prominent political actor and the fascinating, tumultuous life that he led, parts of which remain mysterious. ${ }^{2}$ However, at the same time, there has been a marked neglect shown to the distinct theoretical content of his writings. He is customarily treated as a mere "vulgarizer of Locke," 3 a rhetorician, pamphleteer, and polemicist rather than a political theorist of any note. This attitude is perhaps exemplified by Alasdair MacIntyre's cursory dismissal of Paine's thought as "not a source of philosophical argument." 4

In contrast to most recent scholarship, my objectives in this article are to take the philosophical content of Paine's writing seriously, to show it to be more coherent than is ordinarily assumed, and to identify one area of the history of political thought in which he can be said to have made a strikingly unique contribution: the theory of property rights that he delineated in his pamphlet Agrarian Justice. Most consideration of this work has been of its status as a historical landmark in thinking about social justice, occupied either with gauging the radicalism of Paine's redistributive agenda or with assessing how his thought bridges the concerns of late eighteenth-century republicanism with nineteenth-century socialism. ${ }^{5}$ My interest here is instead in his theoretical justification of private property and how it departs from those of other canonical modern thinkers. In Agrarian Justice Paine offers an account of property rights that fuses his moral commitments

include Moncure Conway, The Life of Thomas Paine (London: Knickerbocker Press, 1892); W. E. Woodward, Tom Paine: America's Grandfather (London: Dutton, 1946); Alfred Owen Aldridge, Man of Reason: The Life of Thomas Paine (London: Cresset Press, 1959); David Freeman Hawke, Paine (New York: Harper and Row, 1974); David Powell, Tom Paine: The Greatest Exile (London: Croom Helm, 1985); A. J. Ayer, Thomas Paine (London: Secker and Warburg, 1988); Jack Fruchtman Jr., Thomas Paine: Apostle of Freedom (New York: Four Walls Eight Windows, 1994). The best studies of Paine's thought are Gregory Claeys, Thomas Paine: Social and Political Thought (London: Unwin Hyman, 1989); Mark Philp, Paine (Oxford: Oxford University Press, 1989); and Jack Fruchtman Jr., Thomas Paine and the Religion of Nature (Baltimore: Johns Hopkins University Press, 1993).

${ }^{2}$ Particularly little is known of Paine's early life. For a discussion of how his enemies tried to make political capital through scurrilous rumors about his private life, see Corinna Wagner, "Loyalist Propaganda and the Scandalous Life of Tom Paine," British Journal for Eighteenth Century Studies 28, no. 1 (2005): 97-115.

${ }^{3}$ Cited in Claeys, Thomas Paine, 2.

${ }^{4}$ Alasdair MacIntyre, A Short History of Ethics (London: Routledge, 1989), 227.

${ }^{5}$ For discussions of the former, see Gertrude Himmelfarb, The Idea of Poverty: England in the Early Industrial Age (London: Faber and Faber, 1984) and Gareth Stedman Jones, An End to Poverty? A Historical Debate (London: Profile, 2004), and of the latter, Thomas Horne, Property Rights and Poverty: Political Argument in Britain, 1605-1834 (Chapel Hill: University of North Carolina Press, 1990) and Gregory Claeys, "The Origins of the Rights of Labor: Republicanism, Commerce, and the Construction of Modern Social Theory in Britain, 1796-1805," Journal of Modern History 66, no. 2 (1994): 249-90. 
to liberty and equality. His stated objective is both to make a redistributive case and "advocate the right ... of all those who have been thrown out of their natural inheritance by the system of landed property" and, at the same time, to "defend the right of the possessor [of property] to the part which is his." ${ }^{6}$ This attempt to simultaneously make the case for both rights of exclusive ownership and significant redistribution of resources might seem at first incoherent. However, as I will argue, Paine's egalitarian case for redistribution is intimately bound up with his libertarian defense of private ownership; in fact, the former might even be thought to stem from the latter.

The structure of the article is as follows. I begin by discussing the moral problem that Paine believes is caused by poverty: how a certain species of poverty is unique to modernity, how it is caused by a lack of property ownership and why it can be described as an injustice. I then move on to consider why Paine rejects a return to a pre-proprietary state and examine his justification of private property rights: the conditions necessary for an agent to justly acquire (and then exclusively own) holdings, from what he claims was an initial community of equally owned goods. I argue that Paine confronts this problem of the move from common to private ownership-prominent within early modern natural law theories - through a variation of John Locke's labor-based account of legitimate acquisition. I suggest that despite the numerous similarities between the accounts offered by Locke and Paine, there are nevertheless fundamental and instructive differences, and I compare the two in order to reveal them.

\section{Property, Poverty, and Moral Equality}

Paine addresses the issue of property ownership most systematically in his pamphlet Agrarian Justice. Despite being one of his most impressively argued works it has attracted relatively little substantial scholarly attention, apart from as an important historical milestone in concerns about social justice and arguments for what looks like an embryonic welfare state. ${ }^{7}$ The pamphlet calls for the establishment of a national fund through government taxation and defends, among other things, what has come to be described as a "stakeholder" income: an unconditional equal endowment paid once to all individuals when they reach majority age. ${ }^{8}$ Composed in France during the

${ }^{6}$ Paine, Agrarian Justice, in The Complete Writings of Thomas Paine, ed. Philip S. Foner (New York: Citadel Press, 1969) [henceforth CW followed by volume number], 1:612.

${ }^{7}$ With some notable exceptions, such as Claeys, Thomas Paine, 196-208 and Philp, Paine, 84-93. For discussion of it within a broader context of arguments for a protowelfare state, see Ben Jackson, “The Conceptual History of Social Justice," Political Studies Review, vol. 3 (2005): 356-73.

${ }^{8}$ Stakeholding payments can be contrasted with unconditional basic incomes because the latter are usually presented as regular payments that take place 
famine-stricken winter of 1795 and 1796, the work remained unpublished in Britain until early 1797, at which point Paine claims to have been motivated by a reading of "An Apology for the Bible" by Richard Watson, the Bishop of Llandaff, a pamphlet that had itself been written in response to his own The Age of Reason. ${ }^{9}$ The closing pages of Watson's book contained a list of his other writings, one of which was a sermon entitled "The Wisdom and Goodness of God, in having made both Rich and Poor." It was to this asserted defense of divinely sanctioned material inequality that Paine felt moved to respond.

His dissatisfaction with Watson's support for material inequalities is best understood not as merely a theological quibble about whether God did indeed validate opulence, poverty, or inequality, but also as a concern to defend equality as a fundamental moral principle. ${ }^{10}$ Indeed, the common thread that runs through all of Paine's political thought is a foundational commitment to "the equality of man."11 "Man is all of one degree," he declares in

throughout a person's life, whereas the former are paid once with the intended effect of generating a civic-minded spirit and sense of responsibility and reciprocity that is thought part of having a "stake" in any society. For discussions, see Keith Dowding, Jurgen De Wispelaere, and Stuart White, eds., The Ethics of Stakeholding (Basingstoke: Palgrave Macmillan, 2003).

${ }^{9}$ Agrarian Justice can be read in the French context of François-Noël Babeuf's ill-fated attempt to establish communism after the Revolution. Nevertheless, though it was a contribution to debates prompted by Babeuf's "conspiracy," Paine maintained that his plan "is not adapted for any particular country alone: the principle on which it is based is general" (Agrarian Justice, 606).

${ }^{10}$ Appreciation of the religious element of Paine's thought is rare, no doubt partly because of the commonplace assumptions of his apostasy that followed his The Age of Reason, which proved to be his most controversial publication, ruining his reputation in his adopted home of America for years-early twentieth-century President Theodore Roosevelt notoriously referred to him as a "filthy little atheist." The Age of Reason lampooned much of Christian doctrine, including the biblical narrative about creation, the concept of miracles, and the divine status of Jesus. Nevertheless, Paine was a deist and did hold a strong belief in God as "first cause" and was highly critical of atheism. His various writings on the subject thus warrant further analysis. Though much more work needs to be done on this virtually ignored part of Paine's writing, useful discussions of The Age of Reason can be found in Claeys, Thomas Paine, 17795; Philp, Paine, 94-113; and Fruchtman, Thomas Paine and the Religion of Nature, 5773. See also Franklyn K. Prochaska, "Thomas Paine's The Age of Reason Revisited," Journal of the History of Ideas 33, no. 4 (1972): 561-76 for a discussion of the critical reception of Paine's most controversial publication.

${ }^{11}$ Paine, The Age of Reason, Part First, CW 1:464. Though Paine's thought developed in interesting ways between the American and French revolutions, his commitment to human moral equality is clearly observable in his early writings, including Common Sense (CW 1:9, 13). Assertion of the equality of "man" raises questions about the relevance of gender and it should be acknowledged that the moral status of women in 
Rights of Man, "and consequently ... all men are born equal and with equal natural rights." ${ }^{12}$ Equality acts as a normative standard for Paine, an axiom from which he derives a catalogue of individual rights and correlative duties. This foundational egalitarian commitment is clearly visible in Agrarian Justice, a work he dedicates to "the Legislature and the Executive Directory of the French Republic," with a warning that "equality is often misunderstood, often misapplied, and often violated." ${ }^{13}$ He starts by arguing (contra Watson) that "it is wrong to say God made rich and poor; He made only male and female; and He gave them the earth for their inheritance." ${ }^{14}$ Yet, as will become clear, in spite of his egalitarian baseline, Paine provides not only a critique of material inequalities, but also an account of the legitimate acquisition of the exclusive property rights that cause and perpetuate those inequalities.

As other commentators have observed, Agrarian Justice consolidates a shift in Paine's economic thought: how he conceptualized what he had regarded earlier as the progressive nature of "civilization" and the commercial economy that characterized it. ${ }^{15}$ Though his early writings reveal an almost unqualified enthusiasm for commerce, this attitude had changed by the early 1790s such that he simultaneously praised and criticized the economic implications of modernity. In 1792, in Rights of Man, Part Two, he retained a commitment to the benefits of "civilized life," which entailed "felicity and affluence," and still considered the "uncivilized" alternative to be marked by "hardship and want." ${ }^{16}$ In making such claims he echoed a sentiment commonplace in seventeenth- and eighteenth-century political thought, one that facilitated cross-cultural economic comparisons. John Locke had declared, in his Second Treatise, that "a King of a large and fruitful Territory" in uncivilized North America "feeds, lodges, and is clad worse than a day Labourer in

Paine's thought is rather unclear. In Rights of Man, he had already argued that "the distinction of sexes" is the only one identified by God (CW 1:274) and he had done likewise in Common Sense (9). However, in none of his writings does he suggest that this distinction legitimates unequal treatment in the political sphere or less than equal rights. Evidence suggests that he was not (as once thought) the author of the critique of female oppression, "An Occasional Letter on the Female Sex," that appeared in the Pennsylvania Magazine in 1775, but Philip Foner includes the letter in Paine's Complete Writings on the grounds that "it indicates his interest as editor of the magazine in the subject, and because some of the language of the essay is his" (CW 2:34-38).

${ }^{12}$ Paine, Rights of Man, 274.

${ }^{13}$ Paine, Agrarian Justice, 606.

${ }^{14}$ Ibid., 609. The fact that immediately following his distinction between sexes Paine says God gave the earth to "them for their inheritance" seems to suggest that not only men received such an inheritance and the rights it entails.

${ }^{15}$ See, for example, Claeys, The French Revolution Debate in Britain: The Origins of Modern Politics (Basingstoke: Palgrave Macmillan, 2007), 38-41.

${ }^{16}$ Paine, Rights of Man, Part Two, CW 1:398. 
England." ${ }^{17}$ Adam Smith made a similar suggestion in The Wealth of Nations, using the example of an African King to argue that "the lowest and most despised member of civilized society" experienced "superior affluence and abundance" over "the most respected and active savage." ${ }^{18}$ By 1792, though, Paine's view on this matter is strikingly different from both Locke's and Smith's. ${ }^{19}$ Alongside his commendation of the great advances made by developed societies and recognition of the want associated with the savage, undeveloped alternatives, he maintains that it "is nevertheless true that a great portion of mankind, in what are called civilized countries, are in a state of poverty and wretchedness far below the condition of an Indian." ${ }^{20}$ Agrarian Justice continues to explore this theme with Paine remarking further on the spectacular material inequalities that have accompanied the otherwise morally and economically progressive emergence of modernity. ${ }^{21}$ For him, "on one side, the spectator is dazzled by splendid appearances; on the other, he is shocked by extremes of wretchedness; both of which it has erected. The most affluent and the most miserable of the human race are to be found in the countries that are called civilized."22

Against the material inequality of modernity, Paine juxtaposes the most primitive societies in North America, which are unblemished by the same degree of human destitution. His conclusion is that a certain kind of poverty is unique to modernity and does not exist in the natural state. ${ }^{23}$ So,

${ }^{17}$ John Locke, Two Treatises of Government, ed. Peter Laslett (Cambridge: Cambridge
University Press, 1988), II, $\$ 41$.
${ }^{18}$ Adam Smith, An Inquiry into the Nature and Causes of the Wealth of Nations, ed. R. H.
Campbell and A. S. Skinner (Indianapolis: Liberty Fund, 1981), I.i.11; Smith, Lectures
on Jurisprudence, ed. R. L. Meek, D. D. Raphael, and P. G. Stein (Indianapolis: Liberty Fund, 1978), 208. Paine was familiar with Smith's Wealth of Nations.

${ }^{19}$ Recent scholarship has presented an interesting understanding of Smith's economic thought as a response to Rousseau's Discourse on the Origin of Inequality, one that championed commercial society whilst also worrying about the problem of significant material inequalities within it. See Dennis Rasmussen, The Problems and Promise of a Commercial Society: Adam Smith's Response to Rousseau (University Park, PA: Pennsylvania State University Press, 2008) and Ryan Patrick Hanley, Adam Smith and the Character of Virtue (Cambridge: Cambridge University Press, 2009). For discussion of Paine in the context of Smith's thought, see Stedman Jones, An End to Poverty? 16-63.

${ }^{20}$ Paine, Rights of Man, Part Two, 398. He is adamant that this is not due to any "natural defect in the principles of civilization, but in preventing those principles having a universal operation" (398).

${ }^{21}$ Thus, he argues that "[t]o preserve the benefits of what is called civilized life, and to remedy at the same time the evil which it has produced, ought to be considered as one of the first objects of reformed legislation" (Agrarian Justice, 609).

${ }^{22}$ Paine, Agrarian Justice, 610.

${ }^{23}$ “To understand what the state of society ought to be, it is necessary to have some idea of the natural and primitive state of man; such as it is at this day among the 
in contrast to Locke and Smith, he suggests that "[t]he life of an Indian is a continual holiday, compared with the poor of Europe." ${ }^{24}$ Paine singles out the emergence of private property as the chief cause of the kind of poverty only found in commercial modernity. He describes as "the greatest evil" the "landed monopoly" that has "dispossessed more than half the inhabitants of every nation of their natural inheritance" and "created a species of poverty and wretchedness that did not exist before." ${ }^{25}$ He argues further:

The present state of civilization is as odious as it is unjust. ... [I]t is necessary that a revolution should be made in it. The contrast of affluence and wretchedness continually meeting and offending the eye, is like dead and living bodies chained together. ${ }^{26}$

This passage clearly shows that Paine views the poverty and inequality of modernity as fundamentally "unjust"; in fact, so much so that it requires a "revolution" of some sort. Since this species of poverty and wretchedness is directly linked to the existence of civilization rather than the natural state, it raises an important moral question about the legitimacy of private ownership and the "landed monopoly" it has enabled.

\section{A Return to the Natural State?}

Paine is, then, unambiguous in his view that civilization has created a new species of poverty as well as increased affluence and that this new poverty is a real moral problem. Property ownership therefore looks in need of some justification. But before turning to his account of legitimate acquisition and ownership, there is a more basic question to address. If poverty is such an important moral issue and there was no such poverty in the natural state, should we not try and return to that state? Paine's answer to this question is interesting. His account of the move from the state of nature to political society in Rights of Man is broadly Lockean in character: in the natural state individuals have natural (moral) rights but then contract into civil society, throwing such rights into a "common stock." ${ }^{27}$ Upon entrance into civil society, individuals surrender their right to punish-which becomes a "civil" right to an impartial arbiter - but retain all other moral entitlements. ${ }^{28}$

Indians of North America. There is not, in that state, any of those spectacles of human misery which poverty and want present to our eyes, in all the towns and streets of Europe" (ibid.).

${ }^{24} \mathrm{Ibid}$.

${ }^{25}$ Ibid., 612.

${ }^{26}$ Ibid., 617.

${ }^{27}$ Paine, Rights of Man, 276.

${ }^{28}$ In the case of punishment, Paine suggests that individuals have a right to "judge in their own cause" but surrender this right to a magistrate because the power to invoke 
For Locke, the question of a return to the state of nature never really arises because the move from the state of nature to society was both a moral and a rational one. The same applies to the establishment of individual property rights: for Locke, "the Condition of Humane Life, which requires Labour and Materials to work on, necessarily introduces private possessions." 29

In his Discourse on the Origin of Inequality, Jean-Jacques Rousseau provides an account of the move away from the natural state that is quite different from Locke's, one in which property ownership also plays a crucial part. Rousseau's narrative explicitly links the emergence of private ownership rights with a corresponding emergence of significant inequalities. Indeed, for Rousseau, the appropriation of property is presented as an act of blatant trickery. He notoriously suggests that "the first man who, having enclosed a piece of ground, bethought himself of saying 'This is mine,' and found people simple enough to believe him, was the real founder of civil society." ${ }^{\prime \prime}$ It is not only the case that Rousseau regards the initial appropriation of property as a contingent event, not, as it is for Locke, a necessary one. In fact, Rousseau is adamant that had the institution of private property rights been avoided or rejected, this could have actually spared the human race innumerable "crimes, wars, and murders": "how many horrors and misfortunes might not any one have saved mankind, by pulling up the stakes, or filling up the ditch, and crying to his fellows: 'Beware of listening to this impostor; you are undone if you once forget the fruits of the earth belong to us all, and the earth itself to nobody.'"'31 The nature of this apparently critical attitude toward the appropriation of property and the inequalities it entails would appear to raise clear moral problems and raise the question of a potential return to the natural state. However, in spite of the disdain for property that Rousseau expresses - and the romantic attachment he has for "natural man" - he rejects outright the possibility that there can be a return to nature. He scorns the idea that individuals should "destroy society, abolish mine and yours and go back to living in the forests with the bears." ${ }^{32}$ For Rousseau, the emergence of civil society from a natural state constitutes a fundamental shift in human nature, from which there simply can be no return.

it becomes redundant once civil society has been generated: "every man takes the arm of the law for his protection, as more effectual than his own; and therefore, every man has an equal right in the formation of the government and of the laws by which he is to be governed and judged" (Paine, Dissertation on First Principles of Government, CW 2:583-84).

${ }^{29}$ Locke, Two Treatises, II, §35, first emphasis mine.

${ }^{30}$ Jean-Jacques Rousseau, Discourse on the Origin of Inequality, in The Social Contract and Discourses, ed. P. D. Jimack (London: Everyman, 1993), 84.

${ }^{31}$ Ibid.

${ }^{32}$ Ibid., 125. 
The relevance of this to our discussion is that Paine, like Rousseau, views a return to the natural state as simply impossible, but offers a quite different reason for this conclusion. Paine's suggestion is that

it is always possible to go from the natural to the civilized state, but it is never possible to go from the civilized to the natural state. The reason is that man in a natural state, subsisting by hunting, requires ten times the quantity of land to range over to procure himself sustenance, than would support him in a civilized state, where the earth is cultivated. ${ }^{33}$

He then adds, crucially, that "there is a necessity of preserving things in that [cultivated] state; because without it there cannot be sustenance for more, perhaps, than a tenth part of its inhabitants." ${ }^{34}$ From this he argues that "the thing, therefore, to be done is to remedy the evils and preserve the benefits that have arisen to society by passing from the natural state to that which is called the civilized state." ${ }^{\prime 35}$ What does this argument actually amount to? Why does Paine insist it is impossible to return to the state of nature? One seemingly plausible interpretation is a utilitarian one. Along these lines, regardless of the existence of widespread, spectacular poverty, civilization has improved its aggregate or overall utility to such a huge extent that it would be morally wrong to abandon such advantages. This would seem to comprise a consequentialist argument in favor of civilization based on a principle of utility or efficiency-civilization can attend the needs of more people, more effectively than the natural alternative. Civilization can accommodate more in the way of resource provisions and therefore there is a moral and rational basis for its emergence and maintenance regardless of the social costs incurred by having a minority of people severely impoverished.

Upon first examination, this interpretation of the logic of Paine's argument does seem reasonable. His focus on the remediation of the evils of civilization whilst maintaining its benefits seems to be a sort of consequentialist compromise, intent on achieving the greatest possible amount of happiness or wellbeing. But Paine is not a utilitarian thinker and this reading of his case for maintaining civilization-rather than returning to a state of nature-must be approached with some caution. ${ }^{36}$ This is because there exists another plausible reading that perhaps fits better with his political theory as a whole. This alternative reading suggests that Paine's argument for maintaining civilization-whilst also remedying the problems of poverty that have accompanied it - is not motivated by considerations of utility or efficiency but is rather rights based. Paine's political writing details a catalogue of

\footnotetext{
${ }^{33}$ Paine, Agrarian Justice, 610.

${ }^{34}$ Ibid.

${ }^{35}$ Ibid.

${ }^{36}$ Paine rarely offers utilitarian arguments and viewing him in that tradition would certainly sit oddly with the central theme that runs throughout his political thought (especially in the 1790s): the inviolability of individual rights.
} 
inviolable rights held by individuals. For example, in Rights of Man, he asserts that individuals have a set of inviolable and equal rights simply by virtue of their existence, such as the right to freedom of religion ${ }^{37}$ and the right to give consent to be governed, ${ }^{38}$ and in Dissertation on First Principles of Government he adds to these the right to democratic representation, ${ }^{39}$ as well as the latent right to rebel against any government that violates fundamental rights. ${ }^{40}$ Throughout the discussion of who is eligible for such rights, Paine is explicit that they apply to the "living" (and to those who shall be "living" in the future); this is a definition of the moral universe constructed in opposition to that of his political nemesis Edmund Burke, whose defense of a principle of inherited sovereignty is in turn represented as a plea to recognize the rights of the dead. ${ }^{41}$ Thus, it seems implicit, though it is not actually spelled out in his theory, that individuals must have, first and foremost, an inviolable right to life or to self-preservation - or put slightly less vaguely, a right to the resources necessary to sustain life. ${ }^{42}$ This seems a prerequisite for all other rights: what would be the point in holding a right to vote, rebel, or whatever, if an agent did not have some right to exist in the first place?

Once this right to life is admitted and emphasized, it is possible to advance an alternative reading of Paine's account of the move from the state of nature to civil society to the utilitarian one. As I noted, the crucial part of his argument for holding on to civilization is that we cannot return to the natural state: it is something that he declares would be "impossible." However, this claim is not the Rousseauian idea that it is physically (or perhaps psychologically) impossible to return to the woods. Rather, the reason for the impossibility of such a return is that the world has, since the move to civilization, become far more "populous" and thus now, a return to the natural state could not provide "sustenance" for more than one tenth of existing individuals. In other words, the problem is not that we are physically unable to abolish ownership and return to a pre-proprietary natural state, but rather that we are morally unable. This is because such a move would threaten the existence of individuals, who, by virtue of existing, have natural inalienable rights. On this understanding it is not that hunting requires more land than agriculture and therefore the latter is to be preferred, but instead that agriculture has, as a matter of fact, supplanted hunting and that there is no way back,

${ }^{37}$ Paine, Rights of Man, 275-76.

${ }^{38}$ Ibid., 251, 254.

${ }^{39}$ Paine, Dissertation on First Principles of Government, 577-78.

${ }^{40}$ Ibid., 580.

${ }^{41}$ See Paine, Rights of Man, 252.

${ }^{42}$ Though modern philosophers would doubtless regard the notion of such a right as hopelessly vague in its formulation, a commitment to the moral duty to preserve human life is a staple of early modern and modern accounts of rights, from (at least) its well-known incarnation in Aquinas to (at least) as far as Locke. 
except through such a way that would sacrifice fundamental individual rights to life. It is the existence or survival of individuals, to which each has an equal right, that is the cornerstone of Paine's political thought. Civilization may have brought a great many benefits for individuals, but this does not seem, technically at least, why Paine wants to maintain it; it is, rather, because of the (as we will see, contingent but not arbitrary) fact that its emergence has created more moral agents who have rights simply by virtue of their existence. Any move away from civilization would entail the perishing of these agents and would therefore be wrong. It is thus possible to conclude that his case is not based on any principle of efficiency or any other consequentialism, except maybe a "consequentialism of rights."

\section{From Common to Private Ownership}

So, to recap: the establishment of private property ownership (as part of the emergence of a commercial economy) has created a morally problematic species of poverty that was absent from pre-proprietary existence, but any proposed abolition of such ownership cannot take place without entailing the perishing of living (rights-bearing) individuals. I turn now to consider how Paine justifies property ownership and how it can be thought intrinsically legitimate - that is to say, beyond the fact that removing it would sacrifice individual lives. While our moral inability to return to the natural state provides a general justification for property ownership as an institution, it does not provide any account of how particular rights can be identified. In other words, the fact that we know that private property rights are legitimate tells us nothing about who can hold them, under which circumstances, and how they are acquired in the first place.

Paine's account of private property rights proceeds from an assumption that is central to natural law theories: that there originally existed a divinely ordained community of goods, within which no individuals held exclusive rights of ownership. "It is a position not to be controverted," he suggests,

... that the earth, in its natural, uncultivated state was, and ever would have continued to be, the common property of the human race. In that state every man would have been born to property. He would have been a joint life proprietor with the rest in the property of the soil, and in all its natural productions, vegetable and animal. ${ }^{43}$

This seems, then, an assertion of a state of original communism: an initial situation in which individuals hold equal rights over the earth's resources. There appears to be no other way of interpreting the notion that the earth is "the common property of the human race" or the idea that individuals were initially its "joint proprietors."

\footnotetext{
${ }^{43}$ Paine, Agrarian Justice, 611.
} 
However, if this is the case, then another obvious question is raised: how did property rights emerge in the first place and how could they ever be legitimate, rather than a violation of individual rights over the "common"? How could any person legitimately claim ownership of a particular portion of land when the earth is a property jointly held by all? This question becomes particularly pointed when it becomes clear that the emergence of private property was a contingent event, without any divine validation. For Paine,

\begin{abstract}
There could be no such thing as landed property originally. Man did not make the earth, and, though he had a natural right to occupy it, he had no right to locate as his property in perpetuity any part of it; neither did the Creator of the earth open a land-office, from whence the first title-deeds should issue. ${ }^{44}$
\end{abstract}

Clearly, then, although individuals had the right to occupy and to use land for their own purposes, such as subsistence, they did not have any divinely ordained right to appropriate it as private property. And as the earlier quotation indicated, he further argues that "the earth, in its natural, uncultivated state was, and ever would have continued to be, the common property of the human race." ${ }^{45}$ Paine is, then, explicit not only that God intended the earth to be "the common property of the human race," but also that were it not for cultivation, it "ever would have continued to be" so. Clearly, then, if there was the possibility that the earth could have remained uncultivated, any cultivation that does subsequently take place must be viewed as a contingent occurrence and thus not necessarily in accordance with any divine will.

In addressing the obvious question of "Whence then, arose the idea of landed property?" Paine invokes a conventional "four-stage" historical narrative by way of explanation. According to this stadial narrative-popular within explanatory accounts of political economy associated with the Scottish Enlightenment ${ }^{46}$-in the first two stages of human existence, property "could not exist." ${ }^{\prime 7}$ In such times, "the use of a well in the dry country of Arabia" was a commonly held right; no individual had exclusive

\footnotetext{
${ }^{44}$ Ibid.

${ }^{45}$ Ibid., emphasis altered.

${ }^{46}$ This "four-stage" account of economic history was a staple of the political thought of the Scottish Enlightenment, in particular Adam Smith's Wealth of Nations. The four stages cited by Smith were that of "hunter," "shepherd," "agriculture," and "commerce." Analyses of the historical development of the four-stage theory can be found in Christopher J. Berry, Social Theory of the Scottish Enlightenment (Edinburgh: Edinburgh University Press, 1997), 93-99; and, beyond the case of the Scots, in Istvan Hont, "The language of sociability and commerce: Samuel Pufendorf and the theoretical foundations of the 'Four-Stages Theory,'" in The Languages of Political Theory in Early-Modern Europe, ed. Anthony Pagden (Cambridge: Cambridge University Press, 1987), 253-76.

${ }^{47}$ Paine, Agrarian Justice, 611.
} 
ownership of it. Private property, understood as exclusively held ownership rights over nonsubsistence resources, only came into being through the "cultivation" of the earth during the third, agricultural, stage of history.

When cultivation began the idea of landed property began with it, from the impossibility of separating the improvement made by cultivation from the earth itself, upon which that improvement was made.... [T]he value of the improvement so far exceeded the value of the natural earth, at that time, as to absorb it; till, in the end, the common right of all became confounded into the cultivated right of the individual. ${ }^{48}$

So, for Paine, although individuals initially commonly owned the earth's natural resources, this altered fundamentally through cultivation and, furthermore, it was this act of cultivation that established individual property rights. After this act has taken place, "the common right of all became confounded into the cultivated right of the individual."

In terms of an explanatory historical-sociological analysis of political economy, Paine's description of the emergence of private property ownership might seem unremarkable and was certainly not unconventional. But there is one highly significant departure from the explanatory emphasis of the fourstage account in Paine's theory: his claim that individuals have fundamental natural rights. Clearly the moral perspective suggested by his invocation of the original communal ownership rights makes very little sense alongside any historicized, sociological account of economic development because the latter relativizes the universal morality purported by the former. The argument so far appears to be that common rights became individual rights simply because it is "impossible" to separate the improvement made by cultivation from the object improved. But how can an individual be seriously said to be a "joint life proprietor" and thus hold an initial right to the earth, if it can subsequently be overridden simply through the cultivations of another? And if individuals have such common rights, how can private property ownership ever be just?

As it stands, Paine's account of private property looks to be extremely problematic, as there is no clear understanding of the moral status of cultivation. Thus far it seems to have been a completely contingent event, something that has simply happened by a chance act of appropriation. Moreover, it is something that seems to have been morally wrong, something that violated individual rights - else there would presumably be no need to provide compensation for those wronged, which is what Paine claims should now happen: there must be "an indemnification for [the] loss" of the natural inheritance. ${ }^{49}$ But if cultivation was wrong in the sense that it violated a right, and individuals now have a right to compensatory justice (through an "indemnification") for the rights violation they have experienced, then (1) should there not be a

\footnotetext{
${ }^{48}$ Ibid., 611-12.

${ }^{49}$ Ibid., 612.
} 
wholesale redistribution of resources along the egalitarian lines suggested by original communism? And (2) should there not be a corresponding punishment of those who have cultivated? Paine's answer to these questions is unambiguous. Those who have cultivated should definitely not be punished and there should not be an egalitarian redistribution of resources. Indeed, he actually argues that cultivation establishes legitimate property rights for the cultivator: his suggestion is that "though every man, as an inhabitant of the earth, is a joint proprietor of it in its natural state, it does not follow that he is a joint proprietor of cultivated earth." ${ }^{50}$ This clearly requires some justification. Why does joint ownership of cultivated land not follow from joint ownership of uncultivated land?

\section{Routes out of Original Communism}

A variety of answers to that question have been offered by early modern and modern theorists, three of which will be explored in turn below. ${ }^{51}$ The first is a "consent" theory that regards property rights as justly arising as the result of conventional agreements. The second is a "first occupancy" justification based on an interpretation of the original community of goods as a situation of "negative communism." The third is the labor theory of legitimate acquisition defended in John Locke's Second Treatise. My aim here is to demonstrate that none of these three rival theoretical approaches adequately captures the nature of Paine's argument, and then to outline his own distinct account of property rights, which both legitimizes libertarian rights of private ownership and demands a form of egalitarian redistribution from the state.

One possible solution to the problem of legitimate private property acquisition within original communism is offered by Pufendorf. This solution concerns the ability of individuals to establish property rights through the consent-either express or tacit-of others. Like Paine, Pufendorf starts from a situation of divinely willed original communism: he suggests that "in the beginning" all the property of the earth was "made available by God to all men indifferently, so that [it] did not belong to one more than to another." 52 God's "proviso" to this original communism was "that men should make such arrangements about them as seemed to be required by the condition of the human race and by the need to preserve peace, tranquillity and good order." ${ }^{53}$ So, "to avoid conflict,"

\footnotetext{
${ }^{50}$ Ibid.

${ }^{51}$ In doing so, I follow the structure of Jeremy Waldron's discussion of natural law theories in The Right to Private Property (Oxford: Clarendon Press, 1988), 149-57.

${ }^{52}$ Samuel Pufendorf, On the Duty of Man and Citizen, ed. James Tully (Cambridge: Cambridge University Press, 1991), 84.

${ }^{53} \mathrm{Ibid}$.
} 
property in things or ownership was introduced by the will of God, with consent among men right from the beginning and with at least a tacit agreement. $^{54}$

For Pufendorf, then, property is something that emerges through actual agreements among individuals that are both necessary and desirable. Therefore it would make little sense to view such appropriation of property as violating any rights. Rather its existence becomes a prerequisite of the exercise of other rights.

Consent would seem capable of closing the gap in Paine's account of the emergence of property. Perhaps what would otherwise be illegitimate acquisitions became legitimate because of the change in circumstances they brought about. Perhaps the fact that a return to a pre-proprietary natural state has morally unacceptable implications opens up a space for tacit or express consent as a mechanism through which ownership rights can be justified. Despite its apparent plausibility, however, there are reasons to discount the possibility that consent justifies property for Paine. Although the idea of consent has a pivotal role in Paine's political theory, particularly his account of the legitimacy of government in Rights of Man, it does so in such a way as to undermine rather than underpin a defense of private ownership rights. For Paine, because consent is a necessary condition of legitimate government, established constitutional arrangements cannot bind future generations: to invoke the authority of constitutional precedent is to violate individual rights to express consent. ${ }^{55}$ Given this view, which makes it illegitimate to bind emerging and future generations to the decisions made by their ancestors without their involvement, it seems unlikely that he would defend the legitimacy of property arrangements with reference to instances of either tacit or express consent. The way in which consent functions in Paine's account of sovereignty suggests that it would not matter if individuals sought peace by establishing a convention approving of private property ownership: it instead suggests that every generation would have the right to think property ownership anew. ${ }^{56}$ Besides all of this, consent is absent from

\footnotetext{
${ }^{54}$ Ibid., $84-85$.

${ }^{55}$ See Rights of Man, especially 249-52, where Paine intervenes in the debate between Richard Price and Edmund Burke about the status and meaning of the English "Glorious Revolution" of 1688. In his A Discourse on the Love of Our Country, Price argued that the constitutional settlement of 1688 established a set of inviolable rights of Britons held against any sovereign monarch, a claim that Burke rejected in his Reflections on the Revolution in France. Paine's response is that it does not matter which account of 1688 is historically accurate, because the members of each generation have the right to give consent to government, thus robbing constitutional arrangements of any permanent legitimacy.

56 "Every generation must be as free to act for itself, in all cases, as the ages and generations which preceded it" (Paine, Rights of Man, 251).
} 
the discussion in Agrarian Justice, so there is not even textual warrant for considering it as a solution.

A second possible explanation of the emergence of justly owned private property involves an alternative way of conceiving of the rights held in the initial situation of communal ownership. By hinting at a rights violation, the discussion so far has traded on the assumption that the community of goods bequeathed by God is a positive one. But what if it makes more sense to view it as a "negative" alternative? The difference between positive and negative forms of original communism comes down to the types of rights each involves. Private property rights over things like land are usually assumed to be "claim rights," in that they generate corresponding duties in (all) other agents to ensure their recognition and forbearance from any actions inimical to their standing. ${ }^{57}$ Thus,

if agent $\mathrm{X}$ has a "claim right" (of ownership) over property $\mathrm{Y}$

then

agent A must forbear from doing action B

where

action B interferes with X's ownership of Y.

In this case, then, if $X$ can establish a claim right over a certain portion of uncultivated earth, then A must forbear from establishing a tobacco plantation on it. If original communism is construed in positive terms, then individuals do have this kind of claim right over natural resources, and Paine's account of the emergence of private ownership involves a blatant violation of individual rights.

But what if original communism should be understood in a "negative" rather than positive sense? This would involve a complete absence of "claim rights" and instead only equally held "privilege" (or "liberty") rights over the earth's resources. All that privileges grant their holder is the lack of a duty to forbear from a certain action. And, unlike with a claim right, the correlative of a privilege is not a duty to forbear from interference but rather just another privilege. So, in a situation of original communism in which individuals hold equal privileges with regards to natural resources, each person would be in the same position: each would have no duty not to act in a certain manner. According to this understanding of the original community of goods, where property is owned in only a negative sense, there are no initial exclusive ownership rights and, because of this, there are also no duties of forbearance from the use of commonly held resources.

${ }^{57}$ I refer here to the taxonomy of legal concepts developed by Wesley N. Hohfeld in Fundamental Legal Conceptions As Applied in Judicial Reasoning, ed. W. W. Cook (New Haven: Yale University Press, 1919). 
Grotius uses this negative understanding of original communism to explain how private ownership rights can be justly acquired, leading to legitimate inequalities in holdings. In doing so, he invokes the analogy made by Cicero with the rights of individuals to seats at a public theatre. According to the Grotian/Ciceronean line, no person has the right to any particular theatre seat, but each is at liberty (so has a privilege) to occupy any one that is vacant, from which he cannot be legitimately ejected. At the same time, no person who fails to occupy a seat has grounds for complaint once there are none left. ${ }^{58}$ For Grotius, the same logic applies to the legitimate acquisition of property. Initially, nothing is actually owned and there exist no obligations to forbear from the use of the world's resources. However, while individuals are under no obligations to forbear from appropriation, they are under obligations to forbear from interference in another individual's act of appropriation. The acquisition of property through first occupancy thus establishes legitimate and exclusive ownership rights.

If Paine's account of property is read along these lines, then the emergence of private property is obviously legitimate because the original ownership rights he identifies are not inviolable claim rights but merely privileges. In this way, although Paine suggests the world was originally "the common property of the human race," this would not entail that it is commonly owned, but rather that it was commonly unowned: there are therefore no duties incumbent upon individuals to refrain from establishing claim rights through cultivation. So, on the negative communist reading, the emergence of private ownership has not been a violation of individual rights. But while this negative reading would immediately solve the apparent contradiction between original communism and private property, it nevertheless also fails to provide an adequate characterization of Paine's theory. This is because his argument is clearly that individuals have more than mere "privilege" rights over the earth as a whole. He is unequivocal in his belief that "all individuals have legitimate birthrights in a certain species of property" and that the propertyless have been robbed of their "natural inheritance." ${ }^{\prime \prime}$ Surely the only way that this can be true is if individuals have inviolable claim rights over natural resources rather than merely privileges. If there are original existing claim rights held by all individuals, it is not a situation of negative communism, and the Grotian analogy of theatre seat allocation is not capable of capturing Paine's theory of property.

One of the most perennially influential justifications of property rights is contained in Locke's Second Treatise. From the same initial premise of original communism, ${ }^{60}$ he argues that rights of private ownership emerge when an

${ }^{58}$ Hugo Grotius, The Rights of War and Peace, ed. Richard Tuck (Indianapolis: Liberty Fund, 2005), 2:420-21. For an excellent discussion of Grotius on property, see John Salter, "Hugo Grotius: Property and Consent," Political Theory 29, no. 4 (2001): 537-55.

${ }^{59}$ Paine, Agrarian Justice, 607.

${ }^{60}$ Locke, Two Treatises, II, §25. 
agent applies her labor to a natural resource. For him, "Every Man has a Property in his own Person," and what follows from this is that any natural resource an agent "hath mixed his Labour with, and joyned to it something that is his own," becomes the exclusive private property of that particular agent. ${ }^{61}$ Thus, the hunter can be said to own the deer he has killed, even though the creature was initially "the common right of every one," because he "hath bestowed his labour upon it." 62 This account of legitimate acquisition based on "labor-mixing" invites a number of problems, the most obvious of which is pursued by Robert Nozick, who asks, "why does mixing one's labor with something make one the owner of it?" "Why," he continues, "isn't mixing what I own with what I don't own a way of losing what I own rather than a way of gaining what I don't?" 63 What Nozick is driving at here is the requirement for Lockean theories of just acquisition to explain what exactly is so special (morally speaking) about labor as an activity and why it generates exclusive property rights. Why does individual industry, initiative, or the like matter for property ownership? But though this might be a question worth asking for Nozick, it is one that Locke can answer unequivocally. Labor is morally significant, for Locke, because it is the subject of divine will: "God, when he gave the World in common to all Mankind, commanded Man also to labour, and the penury of his condition required it of him." ${ }^{64} \mathrm{He}$ argues that

${ }^{61}$ Ibid., II, §27.

${ }^{62} \mathrm{Ibid} ., \mathrm{II}, \S 30$. Such an argument is distinct from the example of theatre seats used by Grotius, which links property ownership merely to first occupancy because the only action the theatre-goer had to engage in is sitting down before somebody else. By contrast, for Locke, the deer belongs to the Indian that killed it rather than, say, his neighbor who managed to sprint more quickly toward it after it died. The act of killing would trump any first occupancy because of the moral relevance of the labor such an act involves.

${ }^{63}$ Nozick, Anarchy, State, and Utopia (Oxford: Blackwell, 1974), 174-75. As he memorably puts it, "If I own a can of tomato juice and spill it in the sea so that its molecules (made radioactive, so I can check this) mingle evenly throughout the sea, do I thereby come to own the sea, or have I foolishly dissipated my tomato juice?"

${ }^{64}$ Locke, Two Treatises, II, §32, emphasis added. There is insufficient space to provide a complete account of Locke's theory of property, the nature of which remains contentious. My reading fits with much recent work on the subject, including the observed "religious turn" in Locke scholarship, which views the justification for and restrictions placed on property ownership as a derivation from his understanding of the law of nature and theologically infused assumptions about morality. For detailed interpretive accounts of Locke's theory of property that stress the theological components, see James Tully, A Discourse on Property: John Locke and His Adversaries (Cambridge: Cambridge University Press, 1981); Waldron, The Right to Private Property, chap. 7; A. John Simmons, The Lockean Theory of Rights (Princeton: Princeton University Press, 1992); Gopal Sreenivisan, The Limits of Lockean Rights in Property (Oxford: Oxford University Press, 1995). For broader analyses of the importance of his theology 
although God "hath given the World to Men in common," he also gave them "reason to make use of it to the best advantage of Life, and convenience." Indeed, natural resources have been "given to Men for the Support and Comfort of their being," and "there must of necessity be a means to appropriate them ... before they can be of use." As several scholars have suggested, the command to labor seems connected to the duty individuals owe to God to maintain their lives, as expressed in his declaration that "Every one ... is bound to preserve himself, and not to quit his Station wilfully." ${ }^{65}$ This duty to preserve life plays a key justificatory role in Locke's argument and gives the activity of labor real moral force.

The assumption that labor carries moral force sufficient to explain the legitimacy of initial acquisition from a situation of original communism certainly provides what looks like a promising strategy for making sense of Paine's arguments. It would show why the act of cultivation establishes rights for the cultivator at the expense of, and to be held against, all others. But there is a clear divergence from Locke's version that requires further explanation. Most obviously, although Paine's natural rights framework contains an oft-downplayed but important theological element, a divine command to labor is neither expressed nor implied. For him, as noted earlier, individual property rights are not part of God's plan for the world but rather a wholly contingent event, one that need not have happened and one that generates the moral problem of poverty: "neither did the Creator of the earth open a land-office, from whence the first title-deeds should issue." ${ }^{66}$ Furthermore, while I suggested earlier that Paine's political theory contains a commitment to a moral right to life and thus selfpreservation, this should not be conflated with any duty of self-preservation, which seems absent from his writing. The ascription of a labor theory of just acquisition to Paine remains plausible, but the lack of divine sanction for it means there is still the lack of any real argument for the rightness of property ownership. If God did not command us to labor, what are the grounds for its moral significance?

for understanding his political thought, see John Dunn, The Political Thought of John Locke: An Historical Account of the "Two Treatises of Government" (Cambridge: Cambridge University Press, 1969); Jeremy Waldron, God, Locke and Equality: Christian Foundations in John Locke's Political Thought (Cambridge: Cambridge University Press, 2002); Paul E. Sigmund, "Jeremy Waldron and the Religious Turn in Locke Scholarship," Review of Politics 67, no. 3 (2005): 407-18.

${ }^{65}$ Locke, Two Treatises, II, $\S 6$. For discussions that stress the relevance of this, see Waldron, The Right to Private Property, 145-47 and Simmons, The Lockean Theory of Rights, 243-52. See also Tully, A Discourse on Property, 131.

${ }^{66}$ Paine, Agrarian Justice, 611. 


\section{Labor, Value, and Creation}

So Locke has a clear response to Nozick's question about what is so special about the activity of labor mixing: it is part of the human duty that individuals owe to God. But Nozick offers his own (nontheological) solution to the problem. He speculates that perhaps "labouring on something improves it and makes it more valuable; and anyone is entitled to own a thing whose value he has created." ${ }^{67}$ Crucially, there are two quite different possible interpretations of this value-based argument that Nozick gestures toward. The argument could be (1) that since labor creates value, it generates rights for the individuals who undertake it; or, alternatively, it could be (2) that labor creates value and therefore generates rights. These arguments look at first to be identical but the ostensibly pedantic difference in word emphasis here is extremely important and points to radically divergent types of argument. The first, value-based, version places moral relevance on some particular value that labor has or teleological end that it satisfies, and, by extension, it is entirely with reference to this value that property rights are justified. This value-based version of the argument states that labor is (for whatever reason) a virtuous or morally praiseworthy action, one capable of establishing rights. The second, creation-based version, by contrast, is uninterested in the "value" created by the labor as such, but instead claims that since whatever has been created was not in existence until it was created, it must belong solely to the creator: after all, who else could plausibly claim a right to it or complain that their rights had been infringed by its creation? This distinction can be used to distinguish Paine's theory in Agrarian Justice from Locke's in the Two Treatises.

Locke does stress the value of labor. In the Second Treatise, he claims:

'tis Labour indeed that puts the difference of value on every thing; and let any one consider, what the difference is between an Acre of Land planted with Tobacco, or Sugar, sown with Wheat or Barley; and an Acre of the same Land lying in common, without any Husbandry upon it, and he will find, that the improvement of labour makes the far greater part of the value. I think it will be but a very modest Computation to say, that of the Products of the Earth useful to the Life of Man 9/10 are the effects of labour: nay, if we will rightly estimate things as they come to our use, and cast up the several Expences about them, what in them is purely owing to Nature, and what to labour, we shall find, that in most of them $99 / 100$ are wholly to be put on the account of labour. ${ }^{68}$

He elsewhere offers the same estimation in slightly modified form and also illustrates the value labor adds to natural resources with various examples. ${ }^{69}$

\footnotetext{
${ }^{67}$ Nozick, Anarchy, State, and Utopia, 175

${ }^{68}$ Locke, Two Treatises, II, $\$ 40$.

${ }^{69}$ Ibid., II, §37.
} 
Without labor, he tells us, individuals would be stuck with "Acorns, Water, and Leaves" rather than with "Bread, Wine and Cloth." ${ }^{70}$ Such an argument would seem to indicate that labor is morally praiseworthy because it improves the value of a natural resource to a highly significant degree. It is not entirely clear how (or whether) this labor theory of value fits exactly with the aforementioned obligation to preserve human life. ${ }^{71}$ Locke does seem to imply that the value created by labor plays some role in the justification of individual ownership: in fact, he introduces his remarks on value in the context of an explanation of why it is not "so strange" that the activity of labor trumps initial use-rights that individuals have in an original community of goods. ${ }^{72}$ It might not be too difficult to incorporate this value-based justification into his theological framework. Perhaps an individual is entitled to an object with which they mix their labor because it adds value to God's creation. On this understanding, labor is morally right not only because it ensures the preservation (or "support") of human agents, but also because it serves a teleological purpose in improving the human situation significantly. ${ }^{73}$

An adherence to a species of the value-creation argument seems immediately recognizable in Paine's theory and therefore able to explain the apparent difficulty faced when moving from a situation of original communism to one of private property. As noted earlier, Paine's seemingly problematic contention is that "in the end, the common right of all became confounded into the cultivated right of the individual" because "the value of the improvement so far exceeded the value of the natural earth." One way of explaining the legitimacy of this move from common to private rights would be through reference to the huge value created by the labor involved in cultivation. On this view, individuals begin in a state of original communism, but can establish legitimate private holdings through labor, provided that the labor exerted increases the value of the natural resource. The question is, however, which of the two value-based arguments identified above he uses: that which places weight on the value or on the creation.

${ }^{70}$ Ibid., II, §42.

${ }^{71}$ Though it should be noted that I do not assume that Locke offers what subsequently came to be known as the "labor theory of value" associated with Smith, Ricardo, and Marx.

${ }^{72}$ Locke, Two Treatises, II, $\S 40$. This use right is outlined at the start of chapter 5: "whether we consider natural Reason, which tells us, that Men, being once born, have a right to their Preservation, and consequently to Meat and Drink, and such other things, as Nature affords for their Subsistence" (II, §25). This passage is occasionally invoked to demonstrate Locke's commitment to a universal right to individual subsistence, but such a claim wrenches the passage from its textual context, which is a presentation of an original (pre-proprietary) community of goods.

${ }^{73}$ For an excellent analysis of the role of labor in Locke's argument "as a kind of purposive activity aimed at satisfying needs or supplying the conveniences of life," see Simmons, The Lockean Theory of Rights, 264-77 (quoted material at 273). 
Paine endorses the activity of labor, praising "cultivation" as "at least one of the greatest natural improvements ever made by human invention." ${ }^{74} \mathrm{He}$ further speculates as to the value it has added to the natural world, concluding - in exact concurrence with Locke - that "it has given to created earth a tenfold value." 75 But it is not Locke's argument about value, but rather the alternative argument about creation that he ultimately endorses. Thus, Paine contends that

the additional value made by cultivation, after the system was admitted, became the property of those who did it, or who inherited it from them, or who purchased it. It originally had no owner. While, therefore, I advocate the right, and interest myself in the hard case of all those who have been thrown out of their natural inheritance by the introduction of the system of landed property, I equally defend the right of the possessor to the part which is his. ${ }^{76}$

This, then, is why "nothing could be more unjust than [communistic] agrarian law in a country improved by cultivation": because it would violate the legitimate entitlements acquired through labor. But the reason that this labor generates rights is not the fact that it creates "value" for the world or maximizes utility or fulfills a divine plan, but rather because it happened to be created by one individual and could therefore belong to no other: thus "it originally had no owner." Another pertinent question asked by Nozick about labor theories of legitimate acquisition is "Why should one's entitlements extend to the whole object rather than just to the added value one's labour has produced?"77 To this, Locke has no real answer other, perhaps, than to fall back onto the idea of an individual physically "mixing" their labor with an object and therefore establishing ownership rights over it. But Paine has an unambiguous response: an individual's entitlement over an object simply does not extend beyond the "added value" one's labor has created. Since his justification of property ownership relies on the importance of the fact that value has been created rather than on the moral value of the creation itself, ownership cannot extend beyond what an individual has added to the natural world.

This justification enables Paine to, in turn, delineate the boundaries of different types of ownership through a distinction between two different types of property, one of which always remains jointly owned even after cultivation and the emergence of private ownership. The two types of property are, "firstly, natural property, or that which comes to us from the Creator of the universe-such as the earth, air, water," and, "secondly, artificial or acquired property - the invention of men." ${ }^{78}$ The value added to a piece of

\footnotetext{
${ }^{74}$ Paine, Agrarian Justice, 612.

${ }^{75} \mathrm{Ibid}$. Like Locke, Paine makes the claim on two different occasions in the text.

${ }^{76}$ Ibid., emphasis added.

${ }^{77}$ Nozick, Anarchy, State, and Utopia, 175.

${ }^{78}$ Paine, Agrarian Justice, 606.
} 
property through labor is, then, "artificial" property, whereas the original land (or the value of the original land) is the "natural" kind. When it comes to "artificial" property, Paine argues that

Equality is impossible; for to distribute it equally it would be necessary that all should have contributed in the same proportion, which can never be the case; and this being the case, every individual would hold on to his own property, as his right share. ${ }^{79}$

This passage might at first be taken to imply that "artificial" property rights are based entirely on "contribution" and that any differences in contribution will generate legitimate inequalities in outcome amongst individual agents. But this is not actually the case. This is because, although labor establishes initial ownership rights, there are numerous other ways in which an individual can subsequently come to hold a legitimate entitlement over a piece of artificial property. In his Dissertation on First Principles of Government, he suggests:

That property will ever be unequal is certain. Industry, superiority of talents, dexterity of management, extreme frugality, fortunate opportunities, or the opposite, or the mean of those things, will ever produce that effect. ${ }^{80}$

This indicates that there are a number of (non-labor based) methods through which individuals can come to own artificial property after an initial acquisition through labor has taken place, and these methods range from contrived thriftiness to plain good luck.

The reason that such seemingly random factors can provide a basis for private property rights comes down to the nature of the rights themselves. It is not effort or industry that determines the distribution of property rights: an agent does not cease to be a proprietor when one chooses to stop working on the land she has cultivated. It is rather the case that property rights entail full ownership powers (of bequest and transfer) over particular holdings. Thus, Paine makes it clear in Agrarian Justice that he is keen to defend the rights not only of the creator of the added value on a piece of property, but also of those "who inherited it from them, or who purchased it." ${ }^{81}$ The rights that the individual has over legitimately owned resources extends beyond the rights to use and to exclude others from using, to include the power to voluntarily transfer the owned resources to other individuals - who then hold the same extensive rights and powers. To put it in Nozickean terms, there is an account of "justice in transfer" embedded in the theory alongside the aforementioned "justice in acquisition." ${ }^{82}$

${ }^{79}$ Ibid.

${ }^{80}$ Paine, Dissertation on First Principles of Government, 580.

${ }^{81}$ Paine, Agrarian Justice, 612.

${ }^{82}$ Nozick, Anarchy, State and Utopia, 150-64. 
Having examined Paine's defense of private property and the corresponding inequalities it creates, we can now turn to consider how this defense actually contains within its logic the case for a potentially radical redistribution of resources. Since acts of labor only establish rights to the value added to a piece of property, even after the establishment of legitimate rights of private ownership of "artificial" property, individuals retain equal, joint ownership of "natural" property, or the original value of the natural world. Paine's claim of equal ownership of natural property - taken together with the fact that it is physically impossible to separate the original from added value because of the nature of ownership-allows him to make the case for a redistribution of resources, a redistribution that will address the modern problem of severe poverty discussed earlier. Because it is not physically possible to make such a separation of value in a particular property holding, Paine claims that each cultivator/owner "owes to the community a ground-rent ... for the land which he holds." ${ }^{\prime 3}$ This ground-rent is to be extracted through state taxation-" "by subtracting from property a portion equal in value to the natural inheritance it has absorbed" ${ }^{84}$ - and redistributed through a single, universal and unconditional, equal endowment to individuals. ${ }^{85}$ Even though the right to own private property can be given a robust justification and the freedoms involved protected, bound up in the nature of this justification is a requirement for substantial redistribution in the name of equality. ${ }^{86}$ This is again quite different from Locke, for whom the initial laborer acquires full ownership of the holding (including the portion of the natural world), which is retained subject to provisos of spoilage and desperate need. ${ }^{87}$

\section{A Third Type of Property and the Limits of State Taxation}

So far Paine's differentiation of natural from artificial property and the basis on which a legitimate right can be held over each seems fairly straightforward. God bequeathed the world to all individuals equally and because of this, a prospective property owner could have legitimate ownership over artificial property by virtue of her cultivation, while also possessing an illegitimately high portion of natural property. If this is the case, the value of the

${ }^{83}$ Paine, Agrarian Justice, 611.

${ }^{84}$ Ibid., 613.

${ }^{85} \mathrm{~A}$ "national fund" will give "to every person, when arrived at the age of twenty-one years, the sum of fifteen pounds sterling" (ibid., 612-13).

${ }^{86}$ It is important to stress that Paine's theory of property rights in Agrarian Justice does not exhaust his account of distributive justice, because he also defends substantial welfare rights based on principles of need. See Paine, Rights of Man, Part Two, and for a discussion, see John W. Seaman, “Thomas Paine: Ransom, Civil Peace, and the Natural Right to Welfare," Political Theory 16, no. 1 (1988): 120-42.

${ }^{87}$ Locke, Two Treatises, II, §38; I, §42. 
natural property should be extracted from the proprietor through taxation, after which all individuals in a political community receive an equal share through a single endowment payment. This all seems perfectly plausible in an agrarian economy, in which land and the agricultural products used on land act as currency. But what does it entail in a commercial economy, where the medium of exchange is money? This question is important as it is land and not money that Paine credits God with bequeathing equally to the human race.

This issue seems especially urgent, since Paine fully admits that his taxation scheme will seek to redistribute not only the value of land, but also "personal property" such as money. Apparently aware of the trickiness of this, he argues that the inclusion of personal property into redistributive calculations is in fact justified by a "different principle" 88 from that of "natural inheritance." He argues that

[p]ersonal property is the effect of society: and it is as impossible for an individual to acquire personal property without the aid of society, as it is for him to make land originally. Separate an individual from society, and give him an island or a continent to possess, and he cannot acquire personal property. He cannot be rich. So inseparably are the means connected with the end, in all cases, that where the former do not exist the latter cannot be obtained. All accumulation, therefore, of personal property, beyond what a man's own hands produce, is derived to him by living in society; and he owes on every principle of justice, of gratitude, and of civilization, a part of that accumulation from whence the whole came. ${ }^{89}$

This analysis - that sees "personal property" as the "effect of society" - fits with Paine's suggestion in Rights of Man, Part Two that "no one man is capable, without the aid of society, of supplying his own wants." 90 The argument seems to be that because the acquisition of money (or perhaps the legal apparatus necessary to sustain its ownership after acquisition) requires the existence of society, justice demands that artificial property like money be taxed in addition to the value of the original natural inheritance that is already eligible for redistribution because it is equally owned.

Gregory Claeys refers to this argument about personal property as the "social debt" principle and describes it as "a second rationale" for redistribution, which is possibly in tension with the primary argument from natural inheritance. $^{91}$ The social debt argument seems to have a somewhat Hobbesian logic that appeals to individual interests: because the security that property requires in order to exist is traceable to the existence of political society, individual property owners owe society something to maintain its

\footnotetext{
${ }^{88}$ Paine, Agrarian Justice, 620.

${ }^{89}$ Ibid.

${ }^{90}$ Paine, Rights of Man, Part Two, 357.

${ }^{91}$ Claeys, Thomas Paine, 202.
} 
existence. But although Paine does describe his social debt argument about personal property as justified by a different principle from that of "natural inheritance," too much stock can be placed in this difference. This is because there is another plausible reading, which casts Paine's social debt principle not as a different principle for the redistribution of property, but rather as signaling a different, third type of property eligible for distribution.

We can see how this alternative reading shapes up by considering what Paine regards as the scope of legitimate state taxation. Claeys suggests that the "notion of such a social debt ... permitted all property, and not only the land, to be taxed or otherwise distributed for the common good." ${ }^{\prime 2}$ But this actually cannot be quite right, as Paine is explicit in his assertion that not all property is eligible for taxation. Though he seems to be heading in that direction at the start of the lengthy passage cited above, the last four lines show him swerve away from such an argument. His concluding contention is that "all accumulation ... of personal property, beyond what a man's own hands produce, is derived to him by living in society; and he owes on every principle of justice, of gratitude, and of civilization, a part of that accumulation from whence the whole came." ${ }^{\prime 3}$ So, all property, except that produced by that individual's labor (by the agent's "own hands") is eligible for taxation. The implication of this is surely that artificial property, which is the product of individual labor, is exclusively owned by the laborer, and nobody else (including the government) can have a claim on it. It is therefore "only a part of" accumulated property that is within the realm of state redistribution. $^{94}$

If this is accepted, it follows that the function of the social debt principle is to introduce another type of property in addition to the two (natural and

\section{${ }^{92}$ Ibid.}

${ }^{93}$ Paine's theory is clearly grounded in markedly atomistic assumptions about human behavior, and he notably does not address the issue of how and whether it is possible for individuals to acquire the physical and intellectual skills necessary to acquire property through improving the land without "living in society."

${ }^{94}$ One of the referees for this article suggested a possible tension between Paine's fundamental commitment to consent as the basis for legitimate government and his commitment to private property rights that are inviolable to taxation: exercises of the former seem entirely capable of undermining the latter. This does not, however, strike me as a real tension, since a commitment to the trumping force of consent seems in some sense fundamental to all libertarian political theories. Thus, as Nozick suggests in his sketch of a libertarian "utopia," "in a free society people may contract into various restrictions which the government may not legitimately impose upon them" (Anarchy, State, and Utopia, 320). So, for example, even in a perfectly libertarian society with inviolable ownership rights over "created artificial property," the proprietors would surely be able to consent to a transfer of property in order to engage in projects intended to benefit whichever community they considered themselves a part of and such projects could conceivably range from building monuments to providing aid to the destitute. 
artificial) already identified by Paine. An example will help to illustrate the distinctness of the three types. Consider an individual who has cultivated some land and has thus appropriated a portion of natural property and whose labor has generated additional value (artificial property), to which that agent now has exclusive rights. For as long as society is filled with this first-generation group of cultivators who have created artificial property by utilizing natural property, there will remain only two types of property. But, as noted above, Paine's account of property rights incorporates the power to bequeath, and when an individual cultivator dies, a third type of property is then created through instances of bequest. This is because the recipient of the bequest can potentially be the possessor (though not necessarily the legitimate owner) of three types of property rather than two. First, the agent in question definitely possesses a portion of "natural" property along with everyone else because of equal inheritance. Second, the person might also possess "artificial" property of their own, should they choose to use the natural property in question to create value. But, third, they could also possess, through bequest, the artificial value created by the testator and not the subsequent possessor. So, rather than just two types of property, there are really three to be distinguished within Paine's account: (1) natural property, (2) created artificial property, and (3) inherited artificial property.

According to Paine's theory, natural property is not owned by the individual cultivator but rather is owned equally and universally and is therefore to be distributed along such lines by the state through taxation. Created artificial property, by contrast, is owned by whoever creates it through their labor and this ownership is full ownership insofar as it is exempt from state taxation and includes the power to bequeath. However, what Paine also seems to arguethrough his "social debt" principle-is that ownership rights over inherited artificial property are in fact not inviolable and can be made subject to taxation. Thus, he insists that government may tax any property "beyond what a man's own hands produce" rather than beyond that which has been produced; the emphasis is on the individual that produced the added value, not the fact that added value has been produced. The ability of the government to tax such property would seem to be somewhat problematic since it would seem to contradict the desire expressed by Paine to defend the ownership rights not only of the creator of added value but also of those "who inherited it from them, or who purchased it." ${ }^{\prime 95}$ But the moral distinction Paine appears to make between created artificial property and inherited artificial property need not contradict his earlier expressed desire to offer a corresponding defense of bequest. Indeed, it only represents a contradiction if Paine's defense of inheritance rights is of absolute rights, that is to say, rights over the whole of the inherited artificial property. Paine's suggestion is notably not that the state confiscate and redistribute all inherited artificial

${ }^{95}$ Paine, Agrarian Justice, 612. 
property, but rather the far weaker claim that all inherited artificial property should be eligible for taxation, which will see some of it removed for purposes of redistribution. The argument would seem to be that inherited artificial property should both be defended (in that it cannot all be removed by the state and should thus reside with the recipient of the bequest) and violable to taxation. Such an argument would also fit with the specific justification that he gives: that without society, an individual would not be able to have personal property in the first place. On this reading there are, then, two different justifications for redistribution present in Agrarian Justice, but this is because there are two different types of artificial property eligible for redistribution in a commercial economy.

\section{Conclusion}

Paine's theory of property was certainly unique among his immediate contemporaries. ${ }^{96}$ But it seems, chiefly through his distinction between "natural" and "artificial" property, his crucial delineation of the boundaries of what is always owned equally and what is always owned individually, to be also unique within the history of modern political ideas. As we have seen, for Paine, private property rights are justly established when individuals deploy their labor to cultivate the natural world. Labor has added

\footnotetext{
${ }^{96}$ Among other things, Paine's belief in divinely willed original communism and his commitment to inviolable rights rather than utilitarianism render his account of property completely different from that advanced by the other major theoretician of $1790 \mathrm{~s}$ British radicalism, William Godwin (in his Enquiry Concerning Political Justice [1798]). The attempt to use Lockean arguments about the significance of labor to justify a redistribution of property in Agrarian Justice is also visible in John Thelwall's The Rights of Nature (1796), which was composed contemporaneously (though the two were on opposite sides of the channel with apparently no knowledge of what the other was writing). However, Thelwall, unlike Paine (but like Godwin), does not appeal to God in his arguments at all; moreover, he justifies the existence of property on partly utilitarian grounds. And Thomas Spence-who, like Paine, did assert that God gave the world to human beings in common-provided a vituperative critique of Agrarian Justice, arguing that the redistributive plans it advocated were "neither just nor satisfactory" and, furthermore, that "Mr. Paine, instead of erecting on this rock of ages an everlasting Temple of Justice, has erected an execrable fabric of compromissory expediency, as if in good earnest for a Swinish Multitude" (Spence, The Rights of Infants, in The Political Works of Thomas Spence, ed. H. T. Dickinson [Newcastle: Avero Publications, 1982], 47). For some discussions of theories of property in the 1790s, see Robert Lamb, "For and Against Ownership: William Godwin's Theory of Property," Review of Politics 71, no. 2 (2009): 275-302; Lamb, "Labour, Contingency, Utility: Thelwall's Theory of Property," in John Thelwall: Radical Romantic and Acquitted Felon, ed. Steve Poole (London: Pickering and Chatto, 2009), 51-60; Claeys "The Origins of the Rights of Labor"; Claeys, The French Revolution Debate in Britain.
} 
value to a commonly held resource and it is the fact that additional value has been created (and can belong to nobody else) that is morally relevant to the justification of private ownership rights rather than any teleological account of the activity that adds such value. This claim simultaneously justifies private property ownership on the one hand and a significant redistribution of resources within a commercial economy on the other. The reason that it justifies such redistribution is that while the value created by the cultivator becomes hers, it remains the case that the original value does not, but remains common property.

At the start of this article, I mentioned the apparently schizophrenic public legacy of Paine's political theory, viewed as libertarian on the one hand and egalitarian, social democratic on the other. The explanation of this, as a matter of historical fact, comes down to the different works read by different audiences. The libertarian reading of Paine's thought popular in the United States comes from the association with his 1776 pamphlet Common Sense, which provided a theoretical case for American independence and the rights to individual freedoms that came with it. The egalitarian reading of Paine's thought popular in Britain comes from the association with his 1791 pamphlet Rights of Man, which provided a withering critique of monarchy and the inequality that came with it. There is no doubt that Paine's thought developed significantly in the years between these two famous pamphlets. ${ }^{97}$ Nevertheless, analysis of Paine's theory of property - with its unified concern with the libertarian right of private ownership and an egalitarian commitment to redistribution - shows that we can reject any notion of schizophrenia or any fundamental incoherence between the concerns that animate his libertarian and egalitarian political agendas. Instead, there are grounds to endorse a reading of his political thought that views it as attempting a synthesis between the foundational liberal values of individual freedom and human moral equality.

${ }^{97}$ For comprehensive accounts of this development, see Claeys, Thomas Paine, especially 39-109 and Philp, Paine. 